\title{
JEMIE
}

\section{Journal on Ethnopolitics and Minority Issues in Europe}

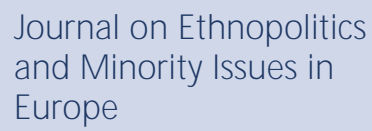

\section{Author:}

Dr Andrea Carlà

Senior Researcher

Eurac Research - Institute

for Minority Rights

andrea.carla@eurac.edu

\section{Acknowledgements:}

The author is grateful to Alexandra C. Budabin for her valuable help. The author thanks Timofey Agarin and the journal's anonymous reviewers as well for their comments. The views expressed herein are those of the author alone.

\section{Fear of Others: Processes of (De)Securitisation in Northern Ireland}

\author{
Andrea Carlà
}

Eurac Research - Institute for Minority Rights

\begin{abstract}
Situated at the junction between the field of ethnic politics, security studies, and migration, this paper analyses processes of (de)securitisation in Northern Ireland. The country is characterised by its violent past, consociational power-sharing institutions, experience with periods of political instability, and the recent arrival of several thousand people from other EU and non-EU countries. As a case study, Northern Ireland epitomises the problems of divided societies and the challenges posed by the presence of competing nationalisms in multinational and ever more diversifying countries. This paper applies the concept of (de)securitisation to analyse the extent to which past conflicts and tensions have been overcome; uncovering who or what is perceived as a threat, according to which terms, and how this affects majority-minority relations.

To conduct the analysis, I adopt the Copenhagen School understanding of securitisation as a speech act. I use a qualitative methodology, examining (de)securitising discourses that emerged in the party programmes of the main political forces which won seats in the Northern Ireland Assembly in 2017 and in previous elections since 1998. I look at the evolution and transformation of such discourses since the Good Friday Agreement of 1998 to today, bringing to light the different security narratives that characterise Northern Ireland concerning the divisions and relationship among its communities and the broader issue of diversity.
\end{abstract}

Keywords: consociationalism; (de)securitisation; discourse analysis; electoral programmes; Northern Ireland; 
Northern Ireland and its 'Troubles' have long epitomised the problems of divided societies and the challenges posed by the presence of competing nationalisms in multinational and diversified countries. The 1998 Good Friday Agreement, with its consociational power-sharing institutions, has brought peace to the country. However, many issues have remained which continue to affect Northern Irish politics, society, and the relationships between its communities. Furthermore, the arrival of several thousand people from other EU and non-EU countries has brought more complexity to Northern Ireland while more recently there are new challenges posed by Brexit's reestablishment of borders between the UK/Northern Ireland and the EU/Ireland.

This article contributes to our understanding of the extent to which Northern Ireland's past conflicts and tensions have been overcome, analysing processes of securitisation and desecuritisation in Northern Ireland's political discourses. The article is situated at the junction between the field of ethnic politics, security studies and migration studies. Developed within the field of security studies, the concept of securitisation refers to the process though which an issue is presented as an existential threat requiring exceptional measures, whereas desecuritisation is the reverse process. In the past decades, several researchers and scholars have applied (de)securitisation to minority issues (e.g., Huysmans, 1995; Olesker, 2014). The concept is a powerful analytical tool for understanding the status of majority-minority relations and the weight of ethnic cleavages in divided societies. Further it brings to light the extent to which institutional, legal, and political instruments of minority accommodation effectively address processes of securitisation.

This article builds on and contributes to this line of research by uncovering (de)securitisation dynamics in Northern Ireland and tracing their evolution. Using the Copenhagen School's understanding of securitisation as a speech act, I conduct a qualitative longitudinal analysis of political discourses as elaborated in electoral programmes of Northern Ireland's parties since the Good Friday agreement to today. The analysis builds a more balanced account of (de)securitisation processes, revealing variation across such processes and showing their evolution and transformation. In this way, I bring to light the different security narratives that characterise Northern Ireland concerning the divisions and relationships among its communities and the broader issue of diversity. The article has four parts. First, I provide a brief overview of studies on (de)securitisation, in particular its application to minority politics, and I situate the article's approach to the process of (de)securitisation and the methodology used in the analysis of Northern Ireland. Second, I present the context by providing an 
historical, institutional, and political overview of Northern Ireland. Then, I trace processes of (de)securitisation and their evolution as they unfolded in the political programmes of Northern Ireland's parties. In concluding remarks, I compare the parties' discourses as they demonstrate desecuritisation dynamics and hint to future lines of research.

\section{Theoretical Framework ${ }^{1}$}

Minority issues have long been linked to security considerations (Kymlicka, 2007; Malloy, 2013, pp. 13-14), however, in the past decades, greater attention has been given to the concept of securitisation, and its inverse: desecuritisation. Developed within the field of security studies, securitisation refers to the process through which an issue is considered as an "existential threat, requiring emergency measures and justifying actions outside the normal bounds of political procedure" (Buzan et al., 1998, pp. 23-24). The so-called Copenhagen School of Security Studies elaborated a constructivist understanding, according to which an issue is securitised not necessarily because a real existential threat exists, but because it is presented as a threat. The concept has been advanced through further theorisation showing different dynamics through which processes of securitisation could happen as well as the context behind it. This has given rise to a range of theoretical frameworks with differing approaches to securitisation. The Copenhagen School considers securitization as a 'speech act' developed in political discourses, accepted and endorsed by a public audience. Meanwhile, sociological approaches highlight the role of historical narratives, social and legal practices, social, cultural, and political contexts, public images and media, institutions, and physical acts (e.g., Jutila, 2015). While the so-called Paris School's applies the concept of bio-politics and focuses on everyday practices, rationalities of governance, methods of social control, and surveillance technologies (e.g., Bigo, 2002). As the antithesis of securitisation, desecuritisation refers to the process by which an issue is no longer considered as a threat and is taken out of the emergency mode. It is a less developed concept which has a variety of understandings (Hansen, 2012).

Securitisation has become a recurrent theme in regard to both 'old' (national, ethnic, linguistic, and religious) minorities as well as research on 'new' minority communities stemming from recent migratory flows. ${ }^{2}$ The securitisation concept has been applied to studies on ethnic conflict and politics of ethno-nationalism, showing how specific national minorities, like Palestinian citizens of Israel, have been securitized; or how all parties involved in tensions/conflicts, as in the case of Northern Ireland, address these tensions in terms of security 
and act as securitising actors (Fabricius, 2013; Olesker, 2014; Van Willigen, 2010). Within migration studies, scholars have shown how various segments of the migrant population (from undocumented migrants to asylum seekers and second/third generations) have been framed in political discourses, media, or government practices as a threat to states' cultural identity and/or their political, economic, and welfare systems (e.g., Huysmans, 1995). Scholars have also addressed the challenge of contesting and reversing such processes of securitisation, in particular the question of how to desecuritise minority issues and minority communities. For example, in regard to Northern Ireland, Donnelly (2015) points out that the agenda of Queen Elizabeth's visit to Northern Ireland in 2011 and her bilingual speech during the visit represented a desecuritising move in the Northern-Ireland question and was an important symbolic gesture that transformed Anglo-Irish relations by presenting Britain as a friend rather than a hostile other. However, desecuritisation of minorities has been mostly debated on the theoretical level (Aradau, 2015; Huysmans, 1995; Roe, 2004). Empirical research on how such a process unfolds in practice is scattered, often lingering on the role of potential desecuritising actors at the international level (Galbreath \& McEvoy, 2012; Nancheva, 2017). Furthermore, research on (de)securitisation tends to focus on a master prevalent narrative that targets a specific minoritarian community. In this way, as pointed out by Bilgic (2013, p. 6), the research "does not reflect the pluralism of the politics of security". The multiple actors and alternative discourses, ideas, and practices embedded in the polity and involved in the politics of security remain ignored.

The concepts of securitisation and desecuritisation are open to multiple interpretations and researchers have adopted different perspectives. As a result, there are extensive debates over what the concepts mean and when, why, and how they happen. It is possible to distinguish two main approaches to securitisation. One perspective, which could be labelled minimalist, focuses on the claiming of a threat and the adoption of an emergency mode and authoritarian moves. However, I argue that when applied to minority issues, this focus on an emergency mode and extraordinary actions beyond normal politics become less relevant, since minority members can be the target of exclusionary and illiberal measures enacted through democratic decision-making process and liberal procedures. The other view, which could be considered maximalist, stresses the development of a friend-enemy distinction and sees securitisation as an ordering principle that shapes communities and their boundaries and, as explained by Guillaume and Huysmans (2013, p. 20) "transfigure[s] alterity into an otherness". Thus, from this perspective securitisation has a strong identity and exclusionary component; through its 
basis in 'us versus them' dichotomy it shapes the boundaries of the communities - defining what and who should be secured and determining what constitutes a threat. Similarly, Balzacq, Depauw, and Leonard (2015, p. 109) distinguish two ideal-type categories of desecuritisation: the "management way" and "transformative way". Considering the management category, Roe (2004) argues that in regard to minority/ethno-national issues it is possible only to manage security issues and normalise minority rights, undoing the emergency mode, because of the specific nature of collective groups and the fact that the maintenance of their distinct identity is a key element that defines them. ${ }^{3}$ Whereas for Jutila (2006), desecuritisation means to transform and rethink the friend-enemy logic and reframe narratives of groups' identities in less exclusionary terms. Thereby, desecuritisation is about "creating an opportunity to incorporate the question of minority rights in the quest for an alternative founding of the political community” (Jutila, 2006, p. 179).

This article adopts a maximalist/transformative understanding of (de)securitisation. I apply this concept of securitisation to deal with minority issues/divided societies - focusing on the definition of threats and processes of othering. Throughout this study securitisation is hereby understood as the subjective process through which an issue is considered as a threat and 'others' (cultural, political, religious, etc.) come to be perceived in primarily exclusionary forms centred on an 'us versus them' dichotomy which implies homogenous entities in opposition or competition. In turn, desecuritisation involves providing a new narrative so that an issue is no longer presented as a threat, unmaking the institutionalised representation of an issue as threatening, and dismantling 'us versus them' categories. Moreover, building on Floyd (2015, p. 128) and Donnelly (2015, p. 917), I consider (de)securitisation not as an outcome with 'tipping points' but as a multifaceted process; a 'sum of actions' without clear beginning or ending, and several shades of greys. Thus, the goal is to explore how (de)securitisation moves emerge, evolve, and dissolve and to trace how different (de)securitising processes develop, overlap and criss-cross. As shown in this article, in Northern Ireland, various (de)securitisation moves coexist and different types of desecuritising discourses have developed. This includes, for instance, speeches that identify a specific threat and adopt confrontational tones coming together with transformative desecuritising narratives recasting the conceptualisation of Northern Irish society in inclusive terms.

The concept of securitisation is a powerful analytical tool that offers new perspectives to advance our understanding of minority issues and policy debates around institutional designs in divided societies. Indeed, it problematises the dynamics, factors, and instruments through 
which negative connotations concerning the presence of minorities develop-providing a better sense of how to comprehensively deal with diversity and encourage peaceful coexistence among communities. Furthermore, as argued by Olesker (2014), the concept of securitisation explains why discriminatory practices persists; illiberal practices are justified and accepted because ethnicity is articulated as a matter of security. Dealing with minorities and divided societies entails more than fostering peace and protecting communities' cultural features and existence, granting rights, dividing powers among the different segments of the population, and/or integrating them in the society at large. It also implies addressing the securitisation/desecuritisation of diversity and minority issues in order to normalise cultural cleavages and minority-majority relations. Thus, it is necessary to uncover to what extent institutional, legal, and political instruments put in place to accommodate minorities and ethnic tensions - such as territorial and non-territorial autonomy, power-sharing, consociationalism, or the establishment of minority language education systems-address processes of securitisation and initiated processes of desecuritisation.

Unfortunately, research on (de)securitisation vis-à-vis minority issues has remained isolated in the sense that, with some exceptions, there has not been much dialogue or knowledge transfer with the extensive scholarship on policy tools to address ethnic issues and deal with minorities, whether old minorities (e.g., power-sharing, consociationalism, minority rights) or new migrant communities (e.g., multicultural policies, intercultural initiatives, civic integration practices). Cross-fertilization between such scholarship and security studies has addressed more traditional security aspects such as the importance of security agreements on police and security force organisation in underpinning peace processes and consociational settlements, debates on demilitarisation and neutralisation, aspects of military security and defence in autonomy arrangements, and security sector reform in post-conflict and transitional societies ( kermark, 2011; McGarry \& O’Leary, 2009; Poullie, 2016; Simons, 2012). There remains much to explore in how institutional and legal/policy solutions interact with (de)securitisation processes. This gap in our understanding is unfortunate as it limits the analytical tools available to discuss and search for effective policies and institutional solutions to deal with minorities and divided societies and govern cultural diversity.

Building on and contributing to previous work on (de)securitisation as it pertains to minority issues, I fill this gap by looking at processes of (de)securitisation and their evolution in Northern Ireland as they unfolded and developed after and in relation to the Good Friday Agreement (GFA). Adopting the Copenhagen School's approach to securitisation as a speech 
act, I focus on political discourses and carry out a critical discourse analysis. In using the Copenhagen School, I am aware of some of its limitations: it excludes other forms of securitisation, focuses on actors with authority, and adopts a logic of exceptions (Bourbeau, 2015; McDonald, 2008). However, looking at speech acts allows for the possibility of tracing variations of (de)securitisation processes over relatively short periods of time (the two decades after the GFA) by relevant political actors. It is also possible to detect how some actors develop overlapping (de)securitisation moves. Other approaches, like the Paris School which looks at routine and patterned practices, make it more difficult to distinguish changes and identify securitising actors (Bourbeau, 2015).

Furthermore, I should stress that I consider political discourses as 'cultural texts' which display narratives and classifications that symbolically construct social reality (Shore \& Wright, 1997). As pointed out by Hattam \& Lowndes (2006; see also Hattam, 2007) the words used are the locus of power where associations are combined and concepts acquire significance. Thus, "public discourse matters" since "the use of codes reveals something significant about public criteria of legitimation" and their analysis helps to understand what are perceived as "the boundaries of the morally permissible" (Carens, 1995, pp. 41-42). In this light, my use of the Copenhagen School approach embraces a discursive institutionalism that highlights the role of discourses and ideas in politics and in constituting political actions in continuous exchange and interaction with the existing institutional and structural context (Schmidt, 2008). In any case, this article reveals just a piece of the puzzle to understand the broader process through which specific articulations of security become lenses of conceptualisation and are able to constitute political communities, capturing the way that communities deal with securitised issues (McDonald 2008). Further research, adopting other approaches, might complement this study.

It should also be noted that, in this context, this article does not address the 'recent' debate on whether the Copenhagen School's theory of securitisation is racist (Howell \& Richter-Montpetit, 2020). Its founders have provided plenty of replies, which I mostly agree with (Wæver \& Buzan, 2020). ${ }^{4}$ What is important is to stress the role of race (as well as ethnicity, language, and religion) and racism in securitisation processes and keep in mind that discourses are the result of power-relations and, in the case of Northern Ireland, centuries of colonisation and conflicts which have framed categories of belonging and racialised/ethnicised insecurity perspectives. Accordingly, there is a pressing need to analyse (de)securitising speeches to reveal what is left of this historical legacy after more than twenty years of the GFA. 
The article aims to uncover the (de)securitisation narratives which developed in Northern Irish political discourses and highlight who or what is perceived as a threat and how this affects minority-majority relations. Following Bilgic (2013), I understand securitisation as a 'continuum' in the sense of the development of simultaneous processes of securitisation and desecuritisation, involving the discourses of a variety of political actors (Jaroszewicz, Krakhmalova \& Grzymski, 2020, p. 3; see also Votradovcová, 2020). Specifically, I consider the political discourses of all the main political parties continuously elected and represented in the Northern Ireland Assembly since the GFA. I focus on the electoral programmes used for the Assembly elections since the agreement; these include the years 1998, 2003, 2007, 2011, 2016, and 2017. In order to provide comparisons with discourses antecedent to the GFA, I also analysed the party programme used for the Westminster parliamentary election in 1997. In the analysis, I focus on the following elements: 1) the 'foregrounding', namely "the prominence given to parts of a text, either by their physical placement or size or by the emphasis given them through word choice ... syntactic structure" or images; 2) the "background', i.e. the "taken-for-granted, usually implicit, elements against which new elements are to be understood by the listener or the reader"; 3) the use of specific 'codes', which consist of a "polarized scheme, dividing the world according to a meaningful distinction"; 4) the 'narrative', which relates to "the report of connected events, real or imaginary, presented in a sequence" (Sciortino, 2019). The elections of the Northern Ireland Assembly (and related party programmes) are ideal points to uncover processes of (de)securitisation since, during these periods, key features and challenges of Northern Irish society are addressed and political actors stake their claims and positions. Furthermore, they represent moments of thoughtful selfreflection by political forces, rather than immediate reactions to specific events that might induce observers to overestimate processes of (de)securitisation.

By looking at party programmes, I consider them as one of the main significant expressions of parties and their approaches. Moreover, their analysis presents several advantages. As Scantamburlo points out in referring to the work of Alonso, Volkens and Gomez (2016, p. 55), electoral programmes represent the position of the entire party rather than a single persons or faction. Furthermore, they are published for every election, and thus it is possible to identify changes and conduct a systematic comparison among parties. At the same time, I am aware that electoral programmes do not reflect in their entirety parties' commitments and actions. Further research that looks, for example, at specific political speeches or party documents, might expand on this work. 
The parties analysed include the Ulster Unionist Party (UUP), Democratic Unionist Party (DUP), Sinn Féin (SF), the Social Democratic and Labour Party (SDLP) and the Alliance Party of Northern Ireland (APNI). The UUP is a centre-right, conservative party, and the most moderate/least loyalist among the unionist political forces. ${ }^{5}$ As the party of David Trimble, one of the main actors in the peace process, it was the main unionist political force at the time of the GFA, but since 2003 it has been overtaken by the DUP, a right-wing, social conservative, Eurosceptic Party which was founded by the evangelical minister Ian Paisley and opposed negotiations with Sinn Féin and the GFA (see Table 1). On the other side of the political spectrum, the SDLP is a left-wing, social-democratic, moderate nationalist political force which is committed to constitutional politics and non-violence. Led by John Hume it was the main nationalist political force during the peace process. In 2003, this role was taken by republican SF, the party historically associated with the IRA and which is characterised as leftwing, democratic socialist, and pro-European. Finally, cutting across the political divide between nationalists and unionists, the APNI is a moderate, liberal, centrist, pro-European party, which has grown gradually in the past decade. In analysing these parties, it should be kept in mind that DUP and Sinn Féin have a broader constituency in the sense that their communication is developed for external consumption: the DUP targets UK constituencies while Sinn Féin also addresses voters in the Republic of Ireland. In contrast, the UUP, SDLP and APNI act as regional parties appealing only to Northern Ireland electorates. This fact might be reflected in their political discourses, though the electoral programmes for the Northern Ireland Assembly election primarily target voters in Northern Ireland. ${ }^{6}$

Table 1

Results in Northern Ireland Assembly Elections - Period 1998-2017 (\% and Seats)

\begin{tabular}{|l|r|r|r|r|r|r|r|r|r|r|}
\hline & \multicolumn{2}{|c|}{ UUP } & \multicolumn{2}{|c|}{ DUP } & \multicolumn{2}{|c|}{ SDLP } & \multicolumn{2}{|c|}{ SF } & \multicolumn{2}{c|}{ APNI } \\
\hline & $\%$ & seats & $\%$ & seats & $\%$ & seats & $\%$ & seats & $\%$ & Seats \\
\hline 1998 & 21.3 & 28 & 18.1 & 20 & 22.0 & 24 & 17.6 & 18 & 6.5 & 6 \\
\hline 2003 & 22.3 & 27 & 25.3 & 30 & 16.7 & 18 & 23.2 & 24 & 3.6 & 6 \\
\hline 2007 & 14.9 & 18 & 30.1 & 36 & 15.2 & 16 & 26.2 & 28 & 5.2 & 7 \\
\hline 2011 & 13.2 & 16 & 30.0 & 38 & 14.2 & 14 & 26.9 & 29 & 7.7 & 8 \\
\hline 2016 & 12.6 & 16 & 29.2 & 38 & 12.0 & 12 & 24.0 & 28 & 7.0 & 8 \\
\hline 2017 & 12.9 & 10 & 28.1 & 28 & 11.9 & 12 & 27.9 & 27 & 9.1 & 8 \\
\hline
\end{tabular}

Note. Data from Torrance (2018, p. 40) 
An analysis of (de)securitising speech acts in Northern Ireland cannot avoid looking at these political forces. Indeed, the UUP, DUP, SDLP, and SF dominated and shaped Northern Ireland's political life before and after the GFA, encompassing both more moderate and more extreme perspectives. APNI has instead represented an alternative but constant voice since the 1970s. In addition, I consider their electoral success as a proxy for public endorsement of their discourses. Before proceeding with the analysis of these discourses, I present a brief historical, institutional, and political overview of Northern Ireland to provide a comprehensive understanding of the context in which these parties discourses are situated and their (de)securitising narratives unfold.

\section{Historical, Institutional, and Political Background}

The 1998 Good Friday Agreement (GFA), or Belfast Agreement, signified the end of the Troubles, a conflict which had bloodied Northern Ireland for decades, leaving over 3,600 dead (the majority of whom were civilians) and more than 30,000 injured. ${ }^{7}$ The Troubles began in the late 1960s when a civil rights and anti-discrimination campaign by the Catholic population turned into a low intensity conflict over the constitutional status of Northern Ireland. The main belligerents were the British army, republican paramilitaries (mainly the Provisional Irish Republican Army, generally referred to as IRA), and loyalist paramilitaries, e.g., Ulster Defence Association/Ulster Freedom Fighters (UDA/UFF) and Ulster Volunteer Force (UVF). The conflict was rooted in the past of plantation/colonisation of Ireland and the arrival of settlers from Great Britain and, after the partition of the island in 1921, decades of political and economic domination by the Protestant majority in Northern Ireland which considered the Catholic population a subversive minority that threatened the existence of their state (Fitzduff \& O'Hagan, 2009). In 1985, following several failed attempts to find a settlement, the UK and Irish governments signed the Anglo-Irish agreement which gave the Republic of Ireland a consultative role in the affairs of Northern Ireland and institutionalised cross-border cooperation to manage the conflict. In addition, the agreement also saw Dublin recognise the existence of Northern Ireland and agree to the 'principle of consent', according to which Northern Ireland should remain part of the UK for as long as a majority of its population wished it to be so (Darby, 2003). Afterwards, as part of a peace process, the IRA and loyalist forces agreed to a ceasefire in 1994 which, among other factors, led to the signing of the GFA. ${ }^{8}$

The Troubles reflect an overlap of religious, ethno-national, and socio-political cleavages and a history of separation, violence, discrimination, and inequalities which has 
maintained the perception of the existence of two distinct groups-reinforcing divisions and leading to significant prejudices and distrust (Byrne et al., 2012; Fitzduff \& O'Hagan, 2009). Though not a direct correlation, there is thus an historic association between religious affiliation, national identity, and political choices, i.e., the contraposition between CatholicIrish-nationalist/republicans vs. Protestant-British-unionist/loyalists (Morrow, 2019, p. 10 \& p. 13). However, the Northern Irish population presents shifting dynamics and complexities in its identities. In this regard, the 2011 census marked a 'watershed' moment in Northern Irish society. The census showed that, for the first time, Protestants and people with Protestant background accounted for less than $50 \%$ of the population (41.5\% and $48 \%$ respectively) whereas $41 \%$ of people defined themselves as Catholic and $45 \%$ as having Catholic background (Morrow, 2019, p. 10). Furthermore, the census presented a significant increase in the number of people that identify as 'Northern Irish' $(21 \%)$ and pointed to a reduction in religious affiliation (Morrow, 2019, p. 12; NISRAa, 2014; NISRAb, 2014). Recent surveys have since confirmed the relevance of the Northern Irish category, though a majority continues to identify with Catholic/Irish and Protestant/British categories (see Table 2 below). Incidentally, the role played by language should be pointed out since "the Irish language question has been at the centre of the Irish/English conflict" as a sign of national identity and mode of resistance, though today only $4 \%$ of the population speaks Irish fluently and $10 \%$ have some ability (Meissner, cit. in Donnelly, 2015, p. 923). In addition, about $8 \%$ of the population have some knowledge of Ulster Scots.

\section{Table 2}

Identity in 2019 - \% of Total Population and by Different Religions

\begin{tabular}{|l|r|r|r|r|}
\hline \multirow{2}{*}{} & \multirow{2}{*}{ Total } & \multicolumn{3}{|c|}{ Religious affiliation } \\
\cline { 3 - 5 } & & Catholic & Protestant & No religion \\
\hline British & 39 & 5 & 69 & 33 \\
\hline Irish & 25 & 62 & 3 & 0 \\
\hline Ulster & 1 & 0 & 23 & 37 \\
\hline Northern Irish & 27 & 26 & 3 & 13 \\
\hline Other answer & 8 & 6 & 1 & 0 \\
\hline Don't know & 0 & 0 & 3 & 0 \\
\hline
\end{tabular}

Note. Elaboration by the author. Data from NILT, 2019.

It should also be noted that in Northern Ireland there is a small Traveller community that numbered about 1,300 persons in 2011. Furthermore, in the past two decades Northern 
Ireland has started to experience the arrival of migrants from foreign countries and, especially after the enlargement of the EU in 2004 and 2007, a "small but significant" East European population (Pehrson et al., 2012, p. 112). According to the 2011 census, $4.5 \%$ of people were born elsewhere in Britain, 2.9\% were born in the Republic of Ireland, and 4.3\% were born elsewhere. Some observers see this development as fostering a pluralist society and an opportunity for political and social change (Morrow, 2019, p. 24).

The Good Friday Agreement was signed by the UK government, the Irish Government, and several of Northern Ireland's political forces. It was endorsed by a majority of the population in Northern Ireland (71\%) and the Republic of Ireland (94\%) and addressed Northern Ireland's divisions by committing the various counterparts to peaceful and democratic mechanisms. The GFA is composed of several elements including: constitutional changes in the Republic of Ireland (removing from its constitution the claim on the entire island); the principle of consent according to which Northern Ireland will remain part of the UK until a majority of the population in both the Republic and Northern Ireland wish this to be changed; a process for decommissioning of weapons by paramilitary forces and the release of paramilitary prisoners; and the creation of an independent commission to deal with policing and criminal justice.

Furthermore, the GFA foresaw three sets of institutions, comprising a consociational system, based on cross-community executive power-sharing, proportionality, mutual veto, and to a lesser extent, segmental autonomy. This consociational system is "built within an overarching confederal and federal" framework (O'Leary cit. in McEvoy, 2015, p. 64). ${ }^{9}$ In this way, the GFA seeks to address relations among Northern Ireland's political forces and communities as well as relations between Northern Ireland and the Republic of Ireland and between the latter and the UK. Based on these aims the GFA establishes the creation of a consociational power-sharing government in Northern Ireland (Assembly and Executive), operating 'on an inclusive basis', with all main political parties included in a coalition government and key decisions taken on a cross-community basis (Darby, 2003). Its main features are:

- An Assembly: composed of 108 members (90 since 2016), elected with the proportional 'Single Transferable Vote' system, who must designate themselves as 'unionist', 'nationalist', or 'other'. It is possible to change political designation, though since 2006 only by changing political party affiliation. The Assembly has power over 
several topics, such as health and social services, culture and sport, housing, and education. However, the UK Parliament — which maintains power on matters such as international relations, nationality, immigration, and asylum-retains sovereignty and can legislate on areas relating to Northern Ireland, though this is done generally only with consent of the Northern Ireland Assembly (see Torrance, 2018, p. 7).

- The use of the d'Hondt procedure: for the formation of the Executive Ministerial seats are allocated on the basis of parties' assembly seat share, with the exception of the Minister of Justice who is appointed by a cross-community vote. In this way complicated post-election negotiations among political forces are avoided (McEvoy, 2015, p. 73).

- An Executive: composed of a First Minister, deputy First Minister, and 11 departmental ministers (8 since 2016). The First Minister and deputy First Minister, who since 2006 are nominated directly respectively by the largest party within the two largest political designations, are the joint heads of government and are required to seek consensus. If it is not possible a vote is taken, and three ministers can require voting on a cross-community basis.

- Cross-community voting procedures: for key decisions in the Assembly such as the approval of the budget, through parallel consent (more than $50 \%$ nationalists and unionists) or weighted majority (60\% of voters, including $40 \%$ unionists and $40 \%$ nationalist).

- The so-called 'petition of concern': through which thirty members of the Assembly can ask to vote with cross-community support.

It should be noted that under the GFA, Northern Ireland is in part considered as a liberal form of consociation in that it "avoids constitutionally entrenching group representation" (McCulloch, 2012, p. 503). Indeed, the election of the Assembly members "does not privilege particular identities" since "the d'Hondt allocation is difference blind" and operates "according to the strength of representation won by parties in the Assembly, not their national identity" (McGarry \& O’Leary, 2009, p. 71).

In addition to this consociational power-sharing government reflecting the Irish dimension of the GFA, the cross-border North-South Ministerial Council fosters cooperation between the Northern Ireland Assembly and Irish Parliament. Its decisions are dependent upon approval by both the Irish Parliament and the Northern Ireland Assembly. Meanwhile, East- 
West relations between the UK and the Republic of Ireland are addressed by the British-Irish Intergovernmental Conference and by the British-Irish Council which is composed of members of the British and Irish governments, the parliaments in Scotland, Wales, and Northern Ireland, and representatives of the Isle of Man and the Channel Islands.

The GFA released tensions, reduced violence, and brought a period of relative peace. However, progress was not straightforward, and many issues remained. First, there were different understandings of the agreement; for example, some unionists saw it as preserving the union with the UK, whereas some nationalists considered it as a transitional step towards a united Ireland. Thus, Laffan speaks in this regard of "uneasy peace rather than deep reconciliation" (cit. in Torrance, 2018, p. 19). Some scholars argue that while the GFA fosters peace and a single political entity at the macro-level, it does not tackle the separation between communities, which are "reified as autonomous "cultural traditions" (Byrne et al., 2012, p. 259; Pehrson et al., 2012, p. 115). Indeed, electoral results show that identity issues continued to polarise the electorate (Morrow, 2019, p. 21). Therefore, politics is "about balancing competing claims to group rights" and identity/cultural disputes are seen as a zero-sum conflict (Byrne et al., 2012, p. 259; Pehrson et al., 2012, p. 115).

The issue of weapons decommissioning was among one of the most conflictual political matters after the GFA as unionists considered it to be a prerequisite for participation in government. The reform of the Northern Irish police force (the Royal Ulster Constabulary; RUC) was also a contentious issue. The RUC was seen as supporting the unionist/protestant population, and in 2001 it was transformed into the the Police Service of Northern Ireland (PSNI) with a policy of 50\% recruitment from people with Catholic background. Furthermore, there were ongoing minor paramilitary activities (like arms importations, smuggling, organised crime $)^{10}$ and at times actions by dissident paramilitary organisations. Various identity-related issues were not resolved, such as the enactment of legislation on Irish language, the holding of parades commemorating key controversial historical events, and the display of flags which at times sparks protests and riots. In this regard it is argued that, since the GFA undid the institutional dominant position of the protestants/unionists, this segment of the population suffered more in the post-GFA period and presented more resentment, cultural anxiety, and higher levels of vulnerability to cultural threats, labelled 'Protestant alienation' (Pehrson et al., 2012, p. 112). In addition, there remains the need to address the legacy of the Troubles and related crimes, as well as past discrimination and inequalities in employment, education, and health care. 
Last but not least, Northern Irish society remained characterised by segregation and sectarianism as well as sectarian hate crimes. Indeed, "self-identification along community lines" endured, affecting several aspects of daily life such as education and housing for Northern Ireland's main communities as well as other minorities (Advisory Committee, 2017, p. 9). As argued by Shirlow (2001; see also Byrne et al., 2012, p. 254), due to fear, mistrust, misunderstanding, and prejudices, some communities tended to remain apart which fostered separation in many ways, for example, in the choice of medical providers and shopping patterns. While various disaggregating shared cultural activities have been put in place by civil society, according to a 2019 report (Morrow, 2019), sectarianism persists and is part of everyday life in many areas. In this regard, it should be noted that sectarian hate crimes were accompanied by a rise in hostility towards migrants and several crimes against other minorities, especially in Protestant areas (Morrow, 2019, p. 28; Pehrson et al., 2012, p. 112). ${ }^{11}$ Furthermore, it has been pointed out that sectarianism interplayed with the aim to foster good relations, understood as the need to avoid contentious issues, justifying in this way a 'donothing' attitude and preventing progress for example in regard to the adoption of Irish language legislation (Advisory Committee, 2017, p. 29). Indeed, in such a context, language has been politicised and transformed into a strong identitarian symbol "perceived as an instrument with the potential to alter the balance between the two main communities", even if issues of language are less relevant in the society and as noted before only a minority of the population speak or know some Irish (Advisory Committee, 2017, p. 7; O’Leary, 2014). The prevalence of sectarianism has had a far-reaching impact, affecting issues related to other minorities and their needs, i.e., Traveller and migrant communities (Advisory Committee, 2017, p. 6).

In light of these issues, the post-GFA Northern Ireland government experienced several difficulties and setbacks (McEvoy, 2015, p. 78). After the 1998 election, in the first Executive which was led by UUP and the SDLP with the participation of Sinn Féin and the DUP, the latter adopted a "half in, half out" approach towards the government, refusing to attend executive meetings and voting against government's policies (McEvoy, 2015, p. 78). Due to lack of progress on the issue of weapons decommissioning, the government was suspended, and direct rule by London was reinstated for several months in 2000, and again from 2002 to 2007-over allegations of the involvement of Sinn Féin in an IRA spy ring. After the IRA announced the end of its armed campaign and its disarmament in 2005, political negotiations sustained by the UK and the Irish government led to the St. Andrews Agreement in 2006. The 
agreement represented a trade-off between the DUP and Sinn Féin, which had become respectively the main unionist and nationalist parties. In the agreement, the former committed to the power-sharing system with republican forces and the latter agreed to support the PSNI. In addition, the agreement foresaw the devolution of policing and justice powers within two years, the introduction of a Ministerial Code,${ }^{12}$ the commitment to develop language strategies for Irish and Ulster Scots, and changes in the functioning of the government including the nomination (rather than cross-community voting) of the First and deputy First Ministers in order to address the DUP's concerns of being elected together and voting for a Sinn Féin representative (McEvoy, 2015, p. 94). ${ }^{13}$

The St. Andrews Agreement signalled political maturity by Northern Ireland's political forces and showed their commitment to maintaining the power-sharing system (McEvoy, 2015, p. 88). At the same time, it has been argued that it reduced elements of cooperation among political forces and increased the potential for rivalry between communities (Morrow, 2019, p. 22). The agreement was followed by a period of improved relationships among political parties and political stability without suspensions of two consecutive assemblies and two executives (2007-2011 and 2011-2016) led by Sinn Féin and the DUP with the participation of the SDLP, UUP (until 2015), and APNI (since 2010). ${ }^{14}$ However, during the 2007-2011 term, political achievements were modest (mainly the transfer of power on policing and justice in 2010 after long negotiation), whereas moments of tensions and contention remained over issues including Irish language legislation and redevelopment plans for the Maze prison: the site of the 1981 hunger strike by republican prisoners. In this period, the 2011 visit of Queen Elizabeth II to the Republic of Ireland with her bilingual opening speech at Dublin Castle was seen as a transformative moment in Anglo-Irish relations and a sign of reconciliation (Donnelly, 2015). However, in Northern Ireland, this moment of reconciliation did not lead to political consensus and progress on minority issues and contested topics such as language. Indeed, as observers point out, sectarianism continued to characterise the political process (Advisory Committee, 2017).

In 2013, Sinn Féin and the DUP launched a new framework entitled "Together: Building a United Community" to address sectarian divisions; however, this framework has been criticized by other political parties. A number of unresolved matters related to issues of identity (parades and flags) and the legacy of the past were addressed in the 2014 Stormont House Agreement and the 2015 Fresh Start Agreement. These agreements foresaw the establishment of a Commission on Flags, Identity, Culture and Tradition; bodies to deal with 
the legacy of the Troubles, including an Oral History Archive and an Historical Investigations Unit; and the devolution to the Northern Ireland Assembly of the responsibility over parades. In addition, some institutional reforms were pursued, e.g., the reduction of numbers of representatives and departments and the possibility for political parties to decline from joining the Northern Ireland Executive and form an official opposition. ${ }^{15}$

Following the 2016 elections the UUP, SDLP and APNI formed the first official opposition of a DUP/Sinn Féin Executive. Soon after, in January 2017, the Executive was suspended over a political scandal and renewed disagreements on Irish language legislation, to be restored only in 2020 with the participation of the UUP, SDLP and APNI. ${ }^{16}$ During this period, London did not impose direct rule; however, as Northern Ireland was missing a fully functioning assembly the UK Parliament legislated on its behalf when necessary, including on devolved issues (Torrance, 2018, p. 30). In particular, Westminster enacted a law that sought to liberalise same-sex marriage and abortion in Northern Ireland in line with the rest of the UK. This measure was highly contested by the DUP and other unionist forces, which had opposed the passing of similar legislation in the Northern Ireland Assembly in previous years (using also the petition of concern). Meanwhile Brexit unfolded, against the will of the majority (56\%) of Northern Ireland's population which had voted to 'Remain' in the 2016 referendum. The discussions which followed regarding the status of Northern Ireland and the reestablishment of borders between the UK and the EU (Ireland) undermined the political co-operation established by the GFA (Morrow, 2019, p. 21). ${ }^{17}$

\section{3. (De)securitisation Processes in Northern Ireland's Political Discourses}

As shown above, Northern Ireland is a complex society with a troubled past. The GFA has brought peace, but the region has since experienced repeated periods of political instability and several contested issues have remained unresolved for years. Below I analyse how Northern Ireland's main political parties addressed the two decades following the agreement, focusing on whether and in what terms they developed and diffused discourses of (de)securitisation visà-vis the relations between Northern Ireland's communities.

\section{$3.1 \mathrm{UPP}$}

Starting within the unionist political arena, in the years preceding the GFA, the UPP presents a defensive attitude. Indeed, its main goal and the title of its 1997 manifesto is to "secure the Union". The party expresses two main concerns: the damages produced by the Anglo-Irish Agreement and direct rule with its "faceless bureaucrats", and the threat posed by IRA/Sinn 
Féin which is wedded to terrorism and "ghetto mentality" (UUP, 1997, pp. 2-3). After the agreement was passed, already in the 1998 party programme, the UUP expresses a feeling of security in regard to its goal to maintain the Union and develops a general dichotomy between those committed to peace versus terrorists. In the following years, this dichotomy turns in a contraposition between unionists and republicans, especially Sinn Féin, who are perceived as having failed to fully decommission and abandon para-militarism. Furthermore, in light of the growth of the DUP, concerns arise over "divisions within unionism" (UUP, 2003). In 2007, with the Assembly suspended in the previous years, the UUP's narrative identifies two main dangers: on the one hand, there are Sinn Féin and the DUP, which are more interested in dividing power and polarising society; on the other hand, there is direct rule, which is considered "unaccountable" and "remote" from people's "hopes and aspirations" (UUP, 2007, p. 32). Over the next years, the UUP assumes that the main problem actually lies in the consociational elements of Stormont's institutions, such as mutual veto and the absence of an opposition, which foster an us-and-them agenda. However, in the 2017 programme, the UUP again identifies Sinn Féin and the DUP — rather than Stormont arrangements - as the major source of Northern Ireland's problems because they play on the “old Orange and Green' lines" (UPP, 2017, p. 3). Meanwhile, in more recent years, UUP narrative again represents, albeit briefly, concerns over terrorist threat and associated criminality. Finally, in 2016, the UUP starts to stress the threat of Brexit and the creation of a 'hard border' between Northern Ireland and the Irish Republic or Great Britain.

These narratives unfold within a persistent and increasingly desecuritising and inclusive understanding of Northern Irish society which embraces diversity and tries to avoid referring to distinctions between Northern Irish communities and traditions. This framework develops from a general appeal to "all our people, whether unionist, nationalist or neither" (UUP, 1997, p. 2), to the commitment to a "multicultural, multi-ethnic society in which everyone plays a part" (UUP, 2003) and calls for "a shared community" and overcoming the "them-and-us battle over ancient squabbles" (UUP, 2007, p. 4, 27). It is epitomised in a subsection of the 2016 programme that addresses identity issues, specifies the party's opposition to the idea of diversity as a "binary carve-up", and speaks of complexity and supporting tolerance, diversity, and minority communities (UUP, 2016, p. 40). However, one year later the party programme clarifies that in its vision of shared community and multiple identities, differences persist, since "it's not about everyone jumping into a virtual blender and emerging the human form of beige" (UUP, 2017, p. 5). This inclusive framework comes together with references to fostering 
integration and tackling sectarianism, and an increasing focus on desegregating the education system and addressing unresolved issues regarding identity, victims of the Troubles, and parades. Furthermore, in the 2011 and 2016 programmes, UUP inclusiveness goes explicitly beyond Northern Ireland's two main traditions to embrace the "growing ethnic and cultural diversity" experienced in previous years due to immigration. This growing diversity is presented as something that should be welcomed and supported, for example, with specific actions to fight discrimination and foster integration (UUP, 2011, p. 34). However, it should be clarified that this inclusive framework exists within a unionist perspective, which is reflected in the emphasis on being part of the United Kingdom (as in the title of the 1998 programme "Together within the Union") and evidenced by opposition to positive discrimination and Irish language bills, support for Ulster Scots, and portrayal of the Union Flag as the only official national flag (UUP, 1998).

\section{$3.2 \mathrm{DUP}$}

Compared to the UUP, the DUP is characterised by more securitising discourses, though with some fluctuations. Moving towards the GFA, the DUP's narrative stresses the threat of an annexation of Northern Ireland by the Republic of Ireland. This is highlighted in the title "Democracy - not Dublin rule!" which elaborates a contraposition between unionists and several dangerous others both outside and inside the unionist community: the British and Dublin governments, which have agreed to force a united Ireland upon unionists; IRA/Sinn Féin, which are combined in the images of "terrorists killing machines" and "mad dogs"; and the Official Unionists, who are deceiving Northern Ireland's people (DUP, 1997, pp. 3-4). In the years following the GFA, this language of fear is maintained and even reinforced with images of terrorists and guns. For example, the DUP speaks of the GFA as "wrecking Northern Ireland", portrays the UUP as "destroying the foundations of unionism", and describes a Sinn Féin/IRA-UUP partnership as a "nightmare" that "may leave unionism fatally weakened" (DUP, 1998; 2003, pp. 2, 3, 12). In addition, the 2003 programme adopts a binary code; assuming a contraposition between protestant/British and catholic/Irish/Gaelic communities, cultures, and identities, which are presented as competing with "British culture and identity no longer in existence in many parts of the Province" (DUP, 2003, p. 3).

Since becoming the largest unionist party, and following the 2006 St. Andrews Agreement, the party starts to move away from the language of fear. This grammar of security disappears in the 2011 programme, following the full term completed by the Assembly with the DUP's leader as First Minister. In the 2007 programme, among past dangers, there remains 
mostly a strong concern with the UUP and a return to the past when unionists were dominated by republican political agenda. Instead, the binomial Sinn Féin/IRA is no longer used and the concern for the threat posed by Sinn Féin in terms of terrorism disappears-replaced by the political concern to defeat Sinn Féin in the electoral arena. At the same time, the party starts to appreciate devolution, though this is understood as a way to "strengthen Northern Ireland's place within the United Kingdom" and highlights the risk of direct rule as it had been experienced in previous years (DUP, 2007, p. 10). Furthermore, concerns are expressed over some of Northern Ireland's consociational arrangements, "which entrench divisions and divide the communit[ies]" searching to normalise politics (DUP, 2011, p. 25).

In this regard, whereas the 2007 programme maintains the dichotomy of unionist versus Irish/Gaelic communities and cultures (though no longer referring to religious markers) in competition over funding under the slogan "pride in who we are", in 2011 these confrontational tones vanished and for the first time DUP refers to working to "build a shared and united community" and breaking down "the barriers which still exist in Northern Ireland between the Province's two historical main traditions" (DUP, 2011, pp. 6-7). In this vision, the DUP includes "those from ethnic communities" that should be "an integral part of building a new Northern Ireland", though the only direct reference is to Ulster-Scots (DUP, 2011, p. 7). However, after years characterised by discussions around cultural issues and the heritage of the Troubles, the 2016 DUP manifesto seems to be a small step back by re-assuming confrontational tones between Northern Ireland's communities. The 2007 slogan "pride in who we are" becomes "taking pride in Northern Ireland" and the party presents a view developed according to a unionist perspective, for example referring to the contested display of the national Union flag (DUP, 2016, p. 30). The year after, the party revamped the competition between unionist and republicans by blaming Sinn Féin for the political crisis and raising the fears of radical republican demands.

\section{$3.3 S D L P$}

On the other side of the political spectrum, SDLP discourses are based on a persistent and increasing desecuritising frame starting from the recognition in the 1997 programme that "we are a divided people" with "different identities" wherein the party aims to bridge communities and foster a shared society (SDLP, 1997, p. 1). This desecuritising and inclusive understanding of society characterises all SDLP party programmes. In 1997, the party's election manifesto emphasised the need to ensure that "diversity is recognised and its expression encouraged" (SDLP, 1997, p. 19). Six years later, the party expressed a will "to cherish and develop all the 
diverse aspects of our national cultures" (SDLP, 2003, p. 24). This idea was carried forward in the 2011 manifesto "Uniting People Building Prosperity" which opposed the idea of "two 'tribes', still unreconciled, but generally at peace" and aimed to transform society into a "North where a united people live, learn and work together" (SDLP, 2011, p. 45). Finally, in 2016 the party's ambition was "to end 'them and us' mentality" and "bring people together in a single community which accommodates its differences and celebrates its diversity" (SDLP, 2016, p. 20). In this vein, the party supports measures to tackle divisions, sectarianism, negative stereotypes, discrimination, and inequalities, increasingly focusing on the problems of the divided education system, which "passes on the old divisions and prejudices of the past to children" (SDLP, 2016, p. 21). Furthermore, and especially since the 2016 programme, the party discourse proposes changes to some of the consociational arrangements, including the revision of the petition of concern and introduction of opposition mechanisms within the power-sharing framework. However, the party is interested in the functioning of the government rather than the repercussions of consociationalism for Northern Irish society.

This inclusive stance is open towards other communities and cultures, ethnic minorities, and migrants. In 1997, the party programme described Travellers' nomadic lifestyle as "a fundamental freedom to be vigorously defended" (SDLP, 1997, p. 14) while in 2011, migrants were defined as "new citizens" who "contribute hugely to our local economy and society" and "must be a part of our Shared Future" (SDLP, 2011, p. 45). However, in 2016, the reference to new citizens disappeared and was reframed as support for EU foreign nationals (SDLP, 2016). At the same time, the SDLP's idea of inclusion is embedded in a concept of Irishness which does not avoid completely the use of binary codes-giving attention to concerns and issues about the Catholic community and Irish cultures and languages. Furthermore, starting in 2003, SDLP programmes prioritise "delivering a United Ireland". A goal to be pursued by persuading unionists of its benefits, promoting North-South cooperation, all-Ireland policies and infrastructure, political participation in the South, and in 2016 under the rubric of "progressive nationalism" by fostering further devolution and fiscal power (SDLP, 2007, p. 10; 2016, p. 5).

Finally, the SDLP narrative shifts from highlighting the contraposition between a past of political and violent conflict and a future of peace thanks to the GFA towards a vague confrontation with those attempting "to wreck the establishment of new institutions" (SDLP, 1998). Since 2003, and increasingly after 2007, the narrative includes contentious tones against specific targets such as the DUP, Sinn Féin, and paramilitaries as well as concerns over direct 
rule (in 2007) and Brexit (after 2016) which is portrayed as "the biggest threat to the economic, social and political interests" of Northern Ireland (SDLP, 2017, p. 3).

\subsection{Sinn Féin}

Looking at Sinn Féin, the Good Friday Agreement has not affected the party’s main narrative with its persistent concern over partition and its goal of unifying Ireland. Indeed, partition created a "failed political and economic unit" and the agreement is seen as just a step towards unity, to be pursued through all-Ireland structures, policies, and cooperation and participation in Irish political institutions (Sinn Féin, 1997). This discourse seems to weaken a bit after the 2003 programme, where the negative consequences of partition are less emphasised. In the 2011 programme, following the first full-term of the Northern Irish power-sharing government, unity remains "the better way" but is combined with the goal of seeking additional powers and financial resources for Northern Ireland's government. However, since 2016 and in light of Brexit and the 100th anniversary of the Easter Rising, the concern for partition returns. Partition is described again as "a disaster" which "has failed the people of the north and south" and reunification is restressed as the party's "mission" (Sinn Féin, 2016, p. 4; 2017, p. 11).

At the same time, the Sinn Féin narrative presents a persistent and increasing call to accommodate divisions and foster equality and inclusion between communities. It focuses on tackling sectarianism and discrimination to create "a society in which Irish people can live together in mutual respect", where "tolerance and equal treatment are standards" and "difference is celebrated and cultural diversity is encouraged" (Sinn Féin, 1997; 2007, p. 41). However, this inclusive narrative, though referring generally to the people of Ireland, assumes and stresses religious/linguistic/national dichotomy by focusing on the concerns of and discriminations suffered by the Catholic/republican/nationalist community. Yet, it should be noted that, since 2011, the party also starts to use a general frame regarding issues of discrimination and inequality. Furthermore, as of 2003, this inclusive approach turned towards a more general call for "multiculturalism", "promoting diversity", and "embrac[ing] the multiethnic, multi-cultural, multi-religious and multi-linguistic diversity in Ireland" with specific measures for the Traveller community and new communities stemming from migration, including Muslims, asylum seekers, and refugees (Sinn Féin, 2003, pp. 89-90). In this regard, migration is seen as "a positive development, something to be welcomed, not feared" which provides the "opportunity to enrich the cultural life of our nation" and "to harness the economic engine of immigration" (Sinn Féin, 2007, p. 47). 
However, Sinn Féin's discourses present some sharp developments. Before the GFA and in the years following, they identify several key adversarial counterparts of the party: the British government, "which demands victory over republicans", and the unionist leadership, which wants to maintain "supremacy, inequality and repression" (Sinn Féin, 1997). Since 2007, this identification of adversaries gives way to a more general concern with direct rule, whose ministers "have taken decisions contrary to the best interests of people" and in 2011, with those who "attempt to drag us back" (Sinn Féin, 2007, p. 18; 2011, p. 2). Nonetheless, in 2016 and 2017, adversarial tones re-emerge as the DUP is portrayed as caring more about its own interests than the community, and the British Tory government is held responsible for imposing austerity measures and Brexit. According to the party, Brexit undermines the GFA and is bad for Northern Ireland economically, politically, and socially.

\subsection{APNI}

Moving beyond the unionist-nationalist political arena, twenty years of the GFA did not change much in the political discourses of the APNI. The party's narrative remained characterised by a desecuritising view of Northern Ireland that avoids the use of binary codes between different segments of the population and processes of othering. These discourses rest on an assumption that the main problem of Northern Ireland is that it is a divided society with sectarianism and racist attitudes. Against this background, before the GFA was passed, the party speaks of and aims at a "Northern Ireland community" which is "based on respect for all rights and traditions and in which all sections of the community can participate" (APNI, 1997, p. 2-3). This goal is a recurring feature in concepts and terms used in APNI programmes over the years. In 2003, the party spoke of "building a united community and creating a shared future" in which diversity is not merely tolerated but "we celebrate diversity and cherish individuality" (2003, pp. 1-2). This idea is carried forward by the vision of an "integrated and shared society" (2016, p. 20). Meanwhile, the mutually reinforcing relationship between equality and good relations is emphasised and the notions of "parallel society of separate but equal" and "Apartheid Northern Ireland" with "tribal politics" are rejected (APNI, 2003, p. 1; 2007, p. 7). Finally, division is portrayed as coming with "economic, financial, human, social ... environmental costs" and "limit[ing] Northern Ireland's potential" (APNI, 2011, p. 26; 2017, p. 14). Thus, the party prioritises fostering good community relations and integration and tackling divisions and sectarianism with various measures in particular through integrated education and shared housing, neighbourhoods, and space. 
The APNI's vision is based on the rejection of a dichotomous understanding of society, identity labels, and "entrenching any particular view of identity" (APNI, 2011, p. 33). Instead, the party sees identity as a choice and recognises the possibility of holding mixed and multiple identities. In this regard, since the 2003 party programme, the party refers to those with mixed marriages/relations, other ethnic minorities, and migrants - who are specifically portrayed as challenging traditional concepts of identity and diversifying Northern Ireland. In 2011, under the slogan "looking outward", the APNI clarifies that migrants should not be asked to assimilate, but rather integrate and in this way positively enrich Northern Ireland's shared society (APNI, 2011, p. 30) whereas, in 2016, the party raises concerns for a rise in racial and religious hatred. In this context, it should be noted that the APNI, more than other parties, looks at Northern Ireland as a distinct entity.

Though since 2007, the APNI notices improvements towards a shared society, this goal has been endangered by both unionists and nationalists pursuing a narrow agenda, political hardliners, and paramilitaries. Such concerns disappeared in the 2011 programme but returned in 2016 when the party pointed out failures of the DUP and Sinn Féin and the threat posed by politicians' incapacity to tackle the controversial issues of parading, flags and the past, which continued to raise tensions. Furthermore, since 2003 the APNI expresses concerns about some consociational elements of the GFA which contribute to "institutionalis[ing] sectarianism", entrenching "intra-ethnic competition" and fostering "politics of 'them' versus 'us' over control of territory and resources". The party proposes institutional changes including the use of weighted majority and voluntary power-sharing coalition, and the reform of the petition of concerns (APNI, 2007, p. 4). Finally, in 2017 the threat of Brexit is presented as having major economic, financial, social, and environmental consequences and clashing with the fundamental agreements that underpin the GFA.

\section{Conclusion}

As shown in the analysis, even before the GFA, Northern Ireland was characterised by a variety of desecuritising discourses that include all the Northern Ireland traditions in a common understanding of society rather than see them as a threat. Such discourses, at least in the electoral programmes, have increased over time following the agreement and the implementation of its consociational mechanisms. These discourses are epitomised by the APNI, which completely avoids the use of binary codes dividing the Northern Irish population. On the other side, there is the more intransigent DUP, which has started to develop 
desecuritising discourses and relax its defensive attitude only since 2011. The desecuritising framework goes beyond the two main Northern Irish communities to sooner or later include other ethnic minorities and, with the exception of the DUP, new minorities stemming from migration whose cultural diversity is in some cases welcome and seen as enriching Northern Irish society (Sinn Féin and the APNI). It is striking that at least in the electoral programmes for the Northern Ireland Assembly (even those of the DUP) securitising moves towards migrants and refugees that are common in many European countries are missing, though Northern Ireland has witnessed cases and episodes of hostility against foreigners.

However, such desecuritising discourses present some limitations since, with the exception of the APNI, they develop within unionist or Irish/republican perspectives and often maintain the use of binary codes and dichotomy which points to a polarised scheme (DUP, SDLP, SF). In this context, it should be stressed that some parties (especially Sinn Féin) have not receded from focusing on the constitutional status of Northern Ireland (a topic further revamped by Brexit), and remarkably the SDLP brought back the issue in 2003 - just five years after the GFA. Furthermore, all analysed Northern Ireland political parties developed, though with some fluctuations, confrontational tones with a variety of external subjects as well as in some cases within their own community of reference (UUP with DUP and vice-versa).

The analysis thus shows how securitisation and desecuritisation are not linear single processes with clear beginnings and endings. Neither do they exclude each other. On the one hand, the desecuritised inclusive understanding of Northern Ireland's society comes together with expressions of fear and the identification of various dangers outside and within each community. On the other hand, Northern Irish parties present different desecuritising inclusive frameworks that may be incompatible with one another. Therefore, there remains the possibility of political conflicts and setbacks.

To conclude, it is possible to observe a correlation between the GFA and some desecuritisation processes. The agreement, with its consociational arrangements, not only brought peace but has created an environment where diverse desecuritisation discourses developed further. At the same time, various issues were left unresolved and raised insecurities in Northern Ireland's communities. In this regard, it is striking to observe that some parties (first the APNI, followed by the DUP, then the UUP, and in part the SDLP) end up requesting the modification of some of the GFA consociational elements, often stressing the problems of the education system. These consociational elements are criticised for fostering 'us vs. them' frameworks and entrenching divisions and are thereby seen as encouraging securitisation 
dynamics. This might reflect the awareness of the limits of the GFA, or in other words, of the fact that in post-GFA Northern Ireland different overlapping (de)securitising discourses develop and interact with the peace agreement.

Further analysis is necessary to consider how such political discourses are endorsed and embraced by the Northern Irish public and understand their consequences for social, policy and legal practices. Furthermore, it remains to be seen how Brexit; considered by most parties as a threat to Northern Ireland, will interplay with such discourses and ongoing desecuritising dynamics. In the Brexit deal, the decision was taken to establish checks and controls along the Irish sea with the possibility for the EU and the UK to suspend such a measure (Northern Ireland Protocol). At the time of writing, recent news surrounding this solution raises concerns for the reactivation of securitisation dynamics and tensions in Northern Ireland; in sum, the future looks grim. 


\section{Notes}

${ }^{1}$ The Theoretical Framework section is partly based on Carlà, 2019.

${ }^{2}$ For the distinction old/new minorities see Medda-Windischer, 2017.

${ }^{3}$ It should be pointed out that Roe (2006) suggests that management in the long run could lead to a transformed understanding of the community.

${ }^{4}$ It might also be sufficient to point out that even the field of political science as emerged in the USA, including most of its founders, were embedded in a racial order (Blatt, 2018); this fact does not imply the need to abandon political science departments.

${ }^{5}$ In the Northern Ireland context, the term 'Unionists' refers to those who aim at maintaining the union with the UK. 'Loyalists' differ in that their main attachment is to the British monarchy and the Protestant heritage, and at times the term is used to imply support for the use of force by paramilitary groups to protect the Union. On the other side of the political spectrum 'Nationalists' aim at the reunification of Ireland and among them 'Republicans' support the use of physical force to obtain this goal (see CAIN Web Service, n.d.).

${ }^{6}$ This point was suggested by T. Agarin in an email exchange with the author.

${ }^{7}$ It is estimated that about half of Northern Ireland's population is linked to those who were killed or injured (Fitzduff \& O’Hagan, 2009).

${ }^{8}$ Several factors sparked and sustained the peace process, including the realisation by both sides that the war could not be won, the decision of the IRA to pursue a political path as well, changes in the socio-economic and international contexts, and the involvement of the USA (Fitzduff \& O'Hagan, 2009).

${ }^{9}$ It should be noted that some scholars debate whether the GFA is wholly consociational (McEvoy, 2015, p. 64).

${ }^{10}$ However, since 2007 such paramilitary activities unfolded mainly in homogenous loyalist or republican areas and thus are not directly related to the tensions among the Northern Ireland communities (Morrow, 2019, p. 29).

${ }^{11}$ Notoriously in 2009, about a hundred Romanian citizens were attacked and forced out of their homes. Many ended up leaving the country, though for the most part they later returned to Northern Ireland.

${ }^{12}$ In this way, Ministers - whose authority is individual and independent of the others - have duties concerning the referral of matters to the Executive.

${ }^{13}$ Furthermore, the agreement foresaw the possibility that thirty members of the Assembly could petition to refer ministerial decisions for Executive review and restrictions to the ability of Assembly members to change their designation, which was subordinated to changes in party affiliation.

${ }^{14}$ UPP left the Executive in 2015 following a murder by the IRA. APNI entered the Executive in 2010 when its leader was elected as first Minister of Justice after the devolution of policing and justice to the Northern Ireland government.

${ }^{15}$ In addition, the Stormont House Agreement addressed issues related to welfare reform and financial tools of the Northern Ireland government.

${ }^{16}$ In 2015, Sinn Féin failed to introduce an Irish language Bill in the Assembly. The Bill, which was opposed by unionists, would have given Irish equal status with English, allowed the use of Irish in courts and in the Assembly and by state bodies, introduced bilingual public signs, and recognized the right to education through Irish.

${ }^{17}$ During the Brexit negotiations between the UK and the EU an agreement has been found according to which a customs border has been re-established between Northern Ireland and the EU/Republic of Ireland de iure but not de facto. 


\section{References}

Advisory Committee on The Framework Convention for the Protection of National Minorities. (2017). Fourth Opinion on the United Kingdom adopted on 25 May 2016. Council of Europe. https://rm.coe.int/16806fb9ab.

Åkermark, S. (2011). Åland's demilitarization and Neutralisation: Continuity and Change. In S. Åkermark (Ed.), The Åland Example and Its Components - Relevance for International Conflict Resolution (pp. 50-71). The Åland Islands Peace Institute.

APNI. (1997). Agenda for Change. The Alliance Manifesto, General Election, 1 May 1997. https://cain.ulster.ac.uk/issues/politics/docs/apni/apni97.pdf.

APNI. (2003). Alliance Works. Manifesto for the Northern Ireland Assembly Elections, 26 November 2003. Alliance Party of Northern Ireland. https://cain.ulster.ac.uk/issues/politics/docs/apni/apni03man.pdf.

APNI. (2007). The Alternative. An Agenda for a United Community. Manifesto, Assembly Election, 7 March 2007. Alliance Party of Northern Ireland. https://cain.ulster.ac.uk/issues/politics/docs/apni/apni270207man.pdf.

APNI. (2011). Alliance Leading Change. Alliance Party Manifesto, Assembly Election 2011. Alliance Party of Northern Ireland. https://d3n8a8pro7vhmx.cloudfront.net/allianceparty/pages/3583/attachments/original/1537971988/ass embly-manifesto-2011.pdf?1537971988.

APNI. (2016). Forward. Faster. Manifesto 2016. Alliance Party of Northern Ireland. https://d3n8a8pro7vhmx.cloudfront.net/allianceparty/pages/3583/attachments/original/1537969097/201 6-alliance-assembly-manifesto.pdf?1537969097.

APNI. (2017). How to change Northern Ireland. For Good. Manifesto 2017. Alliance Party of Northern Ireland. https://d3n8a8pro7vhmx.cloudfront.net/allianceparty/pages/3583/attachments/original/1537969104/201 7-assembly-manifesto.pdf?1537969104.

Aradau, C. (2015). Security as universality. In T. Balzacq (Ed.), Contesting Security (pp. 89-103). Routledge.

Balzacq, T., Depauw S., \& Léonard S. (2015). The political limits of desecuritization. In T. Balzacq (Ed.), Contesting Security (pp. 104-121). Routledge.

Bigo, D. (2002). Security and Immigration: Toward a Critique of the Governmentality of Unease. Alternatives 27, 63-92.

Bilgic, A. (2013). Rethinking Security in the age of Migration. Routledge.

Blatt, J. (2018). Race and the Making of American Political Science. Penn Press. 
Bourbeau, P. (2015). Securitization. In J. D. Wright (Ed.), International Encyclopedia of Social and Behavioral Science (2nd edition, pp. 395-99). Elsevier.

Buzan, B., Wæver, O., \& De Wilde, J. (1998). Security. A New Framework for Analysis. Lynne Rienner Publishers.

Byrne, S., Fissuh, E., Karari, P., Kawser, A., \& Skarlato, O. (2012). Building future coexistence or keeping people apart. International Journal of Conflict Management, 23(3), 248-265.

CAIN Web Service. (n.d.). A Glossary of Terms Related to the Conflict. Accessed September 3, 2020. https://cain.ulster.ac.uk/othelem/glossary.htm.

Carens, J. H. (1995). Is Quebec Nationalism Just? McGill-Queen’s University Press.

Carlà, A. (2019). Fear of “Others”? Processes of securitization in South Tyrol. Research and Science Today, 2(18), 9-25.

Darby, J. (2003). Northern Ireland: The background to the Peace Process. In CAIN Web service - Conflict and Politics in Northern Ireland. https://cain.ulster.ac.uk/events/peace/darby03.htm.

Donnelly, F. (2015). The Queen's speech: Desecuritizing the past, present and future of Anglo-Irish relations. European Journal of International Relations, 21(4), 911-934.

DUP. (1997). '97 Manifesto. Democracy - not Dublin rule! Democratic Unionist Party. https://cain.ulster.ac.uk/issues/politics/docs/dup/dup250698.pdf.

DUP. (1998). Your Best Guarantee for the Future of Northern Ireland. Assembly Election Manifesto 1998. Democratic Unionist Party. https://cain.ulster.ac.uk/issues/politics/docs/dup/dup250698.pdf.

DUP. (2003) Fair deal manifesto 2003. Democratic Unionist Party. https://cain.ulster.ac.uk/issues/politics/docs/dup/dup03man.pdf.

DUP. (2007). Manifesto2007. Getting it Right. Democratic Unionist Party. https://cain.ulster.ac.uk/issues/politics/docs/dup/dup210207man.pdf.

DUP. (2011). Moving forward. Manifesto 2011. Democratic Unionist Party. https://cain.ulster.ac.uk/issues/politics/docs/dup/dup_2011-05-05_man.pdf.

DUP. (2016). Our Plan for Northern Ireland. The DUP Manifesto for the 2016 Northern Ireland Assembly Election. Democratic Unionist Party. https://mydup.com/policies-consultations/2016-assemblyelection-manifesto.

Fabricius, L. (2013). For God and Ulster [Master's Thesis, Lund University].

Fitzduff, M., \& O’Hagan, L. (2009). The Northern Ireland Troubles: INCORE background paper. In CAIN Webservice - Conflict and Politics in Northern Ireland. https://cain.ulster.ac.uk/othelem/incorepaper09.htm. 
Floyd, R. (2015). Just and unjust desecuritization. In T. Balzacq (Ed.), Contesting Security (pp. 122-138). Routledge.

Galbreath, D., \& McEvoy, J. (2012). European organizations and minority rights in Europe: On transforming the securitization dynamic. $S D, 43(3), 267-284$.

Guillaume, X., \& Huysmans, J. (2013). Introduction: citizenship and security. In X. Guillaume \& J. Huy smans (Eds.), Citizenship and security (pp. 1-17). Routledge.

Hansen, L. (2012). Reconstructing desecuritization: the normative-political in the Copenhagen School and directions for how to apply it. Review of International Studies, 38(3), 526-546.

Hattam, V. (2007). In the Shadow of Race. The University of Chicago Press.

Hattam, V., \& Lowndes, J. (2006). The Ground beneath our feet: language, culture and political change. In S. Skowronek \& M. Glassman (Eds.), Formative Acts (pp. 199-222). University of Pennsylvania Press.

Howell, A., \& Richter-Montpetit, M. (2020). Is securitization theory racist? Civilizationism, methodological whiteness, and antiblack thought in the Copenhagen School. Security Dialogue, 51(1), 3-22.

Huysmans, J. (1995). Migrants as a security problem: dangers of 'securitizing' societal issues. In R. Miles \& D. Thränhardt (Eds.), Migration and European Integration (pp. 53-72). Pinter Publishers.

Jaroszewicz, M., Krakhmalova, K., \& Grzymski, J. (2020, August 24-28). Securitisation/de-securitisation of internal displacement in Ukraine as an unintended consequence of the state's resilience building [Paper presentation]. The ECPR Virtual General Conference.

Jutila, M. (2006). Desecuritizing minority rights: Against determinism. Security Dialogue, 37(2), 167-185.

Jutila, M. (2015). Securitization, history, and identity: some conceptual clarifications and examples from politics of Finnish war history. Nationalities Papers, 43(6), 927-943.

Kymlicka, W. (2007). Multicultural Odysseys. Ethnopolitics, 6(4), 585-597.

Malloy, T. (2013). Introduction. In T. Malloy (Ed.), Minority issues in Europe: Rights, Concepts, Policy (pp. 13-23). Frank \& Timme.

McCulloch, A. (2014). Consociational settlements in deeply divided societies: the liberal-corporate distinction. Democratization, 21(3), 501-518.

McDonald, M. (2008). Securitization and the construction of security. European Journal of International Relations, 14(4), 563-587.

McEvoy, J. (2015). Power-Sharing Executives. University of Pennsylvania Press. 
McGarry, J., \& O'Leary, B. (2009). Power shared after the death of thousands. In R. Taylor (Ed.),

Consociational Theory: McGarry and O'Leary and the Northern Ireland Conflict (pp. 15 -84).

Routledge.

Medda-Windischer, R. (2017). Integration of old and new minorities: Beyond a Janus-faced perspective.

European Yearbook of Minority Issues, 14, 1-36.

Morrow, D. (2019). Sectarianism in Northern Ireland: A Review. Ulster University. https://www.ulster.ac.uk/ data/assets/pdf file/0016/410227/A-Review-Addressing-Sectarianism-inNorthern-Ireland FINAL.pdf.

Nancheva, N. (2017). Securitization reversed. Does Europeanization improve minority/majority relations? Südosteuropa, 65(1), 10-34.

NILT. (2019). 2019 Northern Ireland Life and Times Survey. ARK https://www.ark.ac.uk/nilt/2019/Community_Relations/NINATID.html.

NISRAa. (2014). Religion in Northern Ireland. Northern Ireland Statistics and Research Agency. http://www.ninis2.nisra.gov.uk/public/census2011analysis/religion/index.aspx.

NISRAb. (2014). National identity in Northern Ireland. Northern Ireland Statistics and Research Agency. http://www.ninis2.nisra.gov.uk/public/census2011analysis/nationalidentity/index.aspx.

O'Leary, J. (2014, December 17). Why is Irish language divisive issue in Northern Ireland? BBC News. https://www.bbc.com/news/uk-northern-ireland-30517834.

Olesker, R. (2014). National identity and securitization in Israel. Ethnicities, 14(3), 371-391.

Pehrson, S., Gheorghiu, M. A., \& Ireland, T. (2012). Cultural threat and anti-immigrant prejudice: The case of Protestants in Northern Ireland. Journal of Community \& Applied Social Psychology, 22(2), 111-124.

Poullie, Y. (2016). Åland's demilitarization and neutralisation at the end of the Cold War - Parliamentary discussions in Åland and Finland 1988-1995. International Journal on Minority and Group Rights, 23(2), 179-210.

Roe, P. (2006). Reconstructing identities or managing minorities? Desecuritizing minority rights: a response to Jutila. Security Dialogue, 37(3), 425-438.

Roe, P. (2004). Securitization and minority rights: Conditions of desecuritization. Security Dialogue, 35(3), 279-294.

Scantamburlo, M. (2016). Partiti e autodeterminazione in Südtirol/Alto Adige: competizione etnica e strategie dei partiti tra autonomia e secessione [Political parties and self-determination in South Tyrol: Territorial and european party strategies between autonomy and secession]. Nazioni e Regioni, 7 (2016), 47-70. 
Schmidt, V. A. (2008). Discursive institutionalism: the explanatory power of ideas and discourse. Annual Review of Political Science, volume 11, 303-26.

Sciortino, G. (2019, March 19). Critical discourse analysis [Presentation]. Bolzano.

SDLP. (1997). Real Leadership Real Peace. Manifesto. Westmister Parliamentary Election - $1^{\text {st }}$ May 1997. Social Democratic and Labour Party. https://cain.ulster.ac.uk/issues/politics/docs/sdlp/sdlp97.pdf.

SDLP. (1998). Now, Say Yes To A Future Together. SDLP Manifesto. Assembly Election 25 ${ }^{\text {th }}$ June 1998. Social Democratic and Labour Party. https://cain.ulster.ac.uk/issues/politics/docs/sdlp/sdlp98.htm.

SDLP. (2003). Reshaping Government, Rebuilding Public Services. A Manifesto for Equality, Justice \& Prosperity. Social Democratic and Labour Party. https://cain.ulster.ac.uk/issues/politics/docs/sdlp/sdlp03man.pdf.

SDLP. (2007). SDLP Manifesto. Assembly Elections 2007. Let's deliver real progress. Social Democratic and Labour Party. https://cain.ulster.ac.uk/issues/politics/docs/sdlp/sdlp260207man.pdf.

SDLP. (2011). Uniting People. Building Prosperity. SDLP Manifesto. Assembly \& Local Government Elections 2011. Social Democratic and Labour Party. https://cain.ulster.ac.uk/issues/politics/docs/sdlp/sdlp_2011-05-05_man.pdf.

SDLP. (2016). Build a better future. SDLP Manifesto 2016. Social Democratic and Labour Party. https://cain.ulster.ac.uk/issues/politics/docs/sdlp/sdlp_2016-04-11_nia-man.pdf.

SDLP. (2017). Make Change Happen. Manifesto 2017. Social Democratic and Labour Party. https://www.ief.org.uk/wp-content/uploads/2017/02/SDLP-Manifesto-2017.pdf.

Shirlow, P. (2001). Fear and ethnic division. Peace Review, 13(1), 67-74.

Shore, C., \& Wright, S. (1997). Policy a new field of anthropology. In C. Shore \& S. Wright (Eds.), Anthropology of policy critical perspectives on governance and power (pp. 3-39). Routledge.

Simons, G. (2012). Security sector reform and Georgia: the European Union's challenge in the Southern Caucasus. European Security, 21(2), 272-293.

Sinn Féin. (1997). Sinn Féin Westmister Election Manifesto 1997. Building a dynamic for change. Sinn Féin. https://cain.ulster.ac.uk/issues/politics/docs/sf/sf97.pdf.

Sinn Féin. (2003). Agenda for Government. Clár Rialtais. Sinn Féin Assembly Election Manifesto 2003. Sinn Féin. https://cain.ulster.ac.uk/issues/politics/docs/sf/sf03man.pdf.

Sinn Féin. (2007). Sinn Féin Assembly Election Manifesto 2007. Delivering for Ireland's Future. Saoirse, Ceart agus Síocháin. Sinn Féin. https://cain.ulster.ac.uk/issues/politics/docs/sf/sf280207man.pdf.

Sinn Féin. (2011). Leadership Across Ireland. Sinn Féin Assemly Election Manifesto 2011. Sinn Féin. https://cain.ulster.ac.uk/issues/politics/docs/sf/sf_2011-05-05_man.pdf. 
Sinn Féin. (2016). Better with Sinn Féin. Nios Fearr le Sinn Féin. Sinn Féin Manifesto. Assembly Election 2016. Sinn Féin. https://cain.ulster.ac.uk/issues/politics/docs/sf/sf_2016-04-27_nia-man.pdf.

Sinn Féin. (2017). Sinn Féin Assembly Manifesto 2017. Equality Respect Integrity. Sinn Féin. https://cain.ulster.ac.uk/issues/politics/docs/sf/sf_2017-02-15_nia-man.pdf.

Torrance, D. (2018, February 4). Devolution in Northern Ireland, 1998-2018 [Briefing paper CBP 8439]. https://commonslibrary.parliament.uk/research-briefings/cbp-8439/.

UUP. (1997). Secure the Union. Build your future. The Ulster Unionist Party General Election Manifesto $1^{\text {st }}$ May 1997. Ulster Unionist Party. https://cain.ulster.ac.uk/issues/politics/docs/uup/uup97.pdf.

UUP. (1998). Together within the Union. Ulster Unionist Party Manifesto 1998. Ulster Unionist Party. https://cain.ulster.ac.uk/issues/politics/docs/uup/uup98.htm.

UUP. (2003). Ulster Unionists Manifesto 2003. Ulster Unionist Party. https://cain.ulster.ac.uk/issues/politics/docs/uup/uup03man.pdf.

UUP. (2007). For All of Us. Ulster Unionist Party Assembly Election Manifesto 2007. Ulster Unionist Party. https://cain.ulster.ac.uk/issues/politics/docs/uup/uup160207man.pdf.

UUP. (2011). Manifesto / 2011. It's time to make Stormont work - for you. Ulster Unionist Party. https://cain.ulster.ac.uk/issues/politics/docs/uup/uup_2011-05-05_man.pdf.

UUP. (2016). Northern Ireland Assembly. Manifesto 2016. \#MakeItWork. Ulster Unionist Party. https://uup.org/assets/policies/assembly\%20manifesto.pdf.

UUP. (2017). Manifesto 2017. A manifesto for real partnership. Ulster Unionist Party. https://uup.org/assets/policies/uup\%20ae17.pdf.

Van Willigen, N. (2010). From nation-building to desecuritization in Bosnia and Herzegovina. Security and Human Rights, 21(2), 127-138.

Votradovcová, H. (2020, August 24-28). Context, audience and reframing of a failed case of (de)securitisation of migration in the Czech Republic [Paper presentation]. The ECPR Virtual General Conference.

Wæver O., \& Buzan, B. (2020). Racism and responsibility - The critical limits of deepfake methodology in security studies: A reply to Howell and Richter-Montpetit. Security Dialogue, 51(4), 386-394. 